\title{
Grid-Connected SVPWM System Analysis and Control of Quasi-Z Source Inverter bith Battery Improvement: Comparative Analysis of MPPT in Solar Panel with Respect to Power
}

\author{
Ghulam Rabani ${ }^{1}$, Shekhar Verma ${ }^{2}$ \\ ${ }^{2}$ Assistant Professor, Department of Electrical Engineering, EMAX Group of Colleges, Haryana, India
}

\begin{abstract}
The most extreme power conveyance to the heap is guaranteed by a versatile neuron fuzzy deduction framework (ANFIS) in view of greatest power point following framework (MPPT). The ANFIS-based MPPT offers a to a great degree quick element reaction with high precision framework. An altered space vector modulation (SVPWM) method for the qZSI is connected to accomplish low noise, high voltage usage, power variable change and high effectiveness. A P-Q decoupled lattice tie power infusion is satisfied with the most extreme power catch from PV boards and the solidarity power component. The legitimacy of the proposed PV framework is demonstrated by test results, demonstrating a productive strategy for the energy put away PV power generation.
\end{abstract}

Keywords: MPPT, PV characteristics, SVPWM, Solar Panel, Solar energy, Temperature

\section{Introduction}

The Z-source inverter (ZSI) and quasi Z-source inverter (qZSI) have been utilized for PV power generation framework because of some one of a kind elements and points of interest [1]. PV board outcomes a fluctuating power because of the variety of solar oriented light and temperature. A energy storage framework could be included the framework to smooth the vacillation of network infused power, where the battery is associated with the framework either by an additional DC/DC converter in the DC side or by an additional DC/AC converter in the AC side. These structures make the power generation framework more enhanced and costly, low productivity and low dependability.

This paper will propose another PV interface inverter through incorporating qZSI with battery. Its working rule, parameter plan strategy, and point by point examination are explored. Two control variables, i.e., the shoot-through obligation proportion and the regulation list are utilized to control the outcome power of PV board, the power infused to the framework, and the condition of charge (SOC) of battery [2]. MPPT algorithm guarantees the PV boards' most extreme power point (MPP) all the time [2]. Recreation results and exploratory results confirm the proposed circuit, hypothetical investigation, and control plan.

The most extreme possible outcome voltage can't surpass the DC include and can deliver a voltage lower than the DC info voltage. Voltage source inverter can expect just eight particular topologies. Six topologies creates a non-zero outcome voltage and are known as non-zero switching states and the staying two topologies produces zero outcome voltage and are known as zero switching states [3].

\section{A. Quasi-Z-Source Inverter}

The quasi z-source inverter (QZSI) is a solitary stage power converter got from the Z-source inverter (ZSI) topology, utilizing an impedance system. The impedance system couples the source and the inverter to accomplish voltage help and reversal in a solitary stage. Both ZSI and qZSI conquer the disadvantages of VSI and CSI by using a few Shoot through (ST) zero states. A zero state is created when the upper three or lower three switches are let go all the while to help the outcome voltage. Maintaining the six allowable dynamic switching conditions of a VSI, the zero states can be in part or totally supplanted by the shoot through states relying on the voltage help necessity. The inverter draws a consistent current from the PV exhibit and is equipped for taking care of a wide information voltage range [4]. It additionally highlights lower part appraisals, diminishes changing waves to the PV boards, and causes less EMI issues and lessened source stress contrasted with the ZSI.

\section{B. QZSI Network}

The impedance system in QZSI varies from that of a ZSI. This system goes about as an interface between the source and the inverter. The impedance system of QZSI is a two port system. It comprises of inductors and capacitors. The LC impedance system and the diode associated with the inverter span adjust the circuit operation, permitting the shoot-through state and shield the circuit from harm when the shoot through happens. By utilizing the shoot-however express, the quasi $\mathrm{Z}$ source system supports the dc-join voltage the dc source can be a battery, diode rectifier, thyrist or converter or PV exhibit. The outcome voltage of the QZSI is controlled and the outcome power is dictated by relating load demands [5].

\section{Objectives of the paper:}

- The rate of the algorithm in finding the right working purpose of PV is a critical consider particularly while working lattice intuitive mode.

- The proposed method of utilizing ANFIS-based MPPT offers exceptionally exact and quick control with vigorous 


\section{International Journal of Science and Research (IJSR)

operation and is exceedingly appropriate for miniaturized scale lattice application in PV era frameworks.

\section{Background Studies}

Proposed approach is based on following studies:

Fang Zheng Peng et al (2005) showed Z source inverter framework for customizable velocity drives (ASD) to have ride through capacity under voltage droops, lessened line noise, and augmented outcome voltage range with recreation and trial results [6]. A two level voltage sort $\mathrm{Z}$ source inverter for photovoltaic frameworks was proposed by Yi Huang et al (2006) to acknowledge reversal and support capacity in one single stage with outline rule utilizing straightforward help control as switching plan [7].

Simulation and downsized lab model of three levels $\mathrm{Z}$ source impartial point cinched inverter utilizing a solitary LC impedance system was exhibited by Poh Chiang Loh et al (2007). Configuration of a double $\mathrm{Z}$ source inverter utilized with either a solitary dc source or two disengaged dc sources was proposed by Feng GAO et al (2007). Hypothetical discoveries, together with the inverter common sense of the double $\mathrm{Z}$ source inverter was affirmed in reproductions both utilizing PSIM with MATLAB/Simulink coupler and tentatively by utilizing a research facility executed inverter model [7].

Poh Chiang Loh et al (2008) displayed the advancement of two three level fell $\mathrm{Z}$ source inverters with maybe a couple impedance systems in the front end controlled utilizing distinctive regulation methodologies, for example, stage demeanor and stage moved transporter switching plans [8].

\section{Proposed Work}

Operating Principle of QZSI

The two modes of operation of a quasi z-source inverter are:

(1) Shoot through mode.

(2) Non-shoot through mode (active mode).

\section{a) Active Mode}

In the non-shoot through mode, the switching design for the QZSI is like that of a VSI. The inverter span, saw from the DC side is comparable to a present source, the info dc voltage is accessible as DC connection voltage contribution to the inverter, which makes the QZSI carry on like a VSI. A persistent current moves through the diode D1 [9]

\section{b) Shoot Through Mode}

In the shoot through mode, switches of the same stage in the inverter scaffold are switched $\mathrm{ON}$ at the same time for a brief length. The source however does not get short circuited when endeavored to do as such due to the nearness LC system, while boosting the outcome voltage. The DC join voltage amid the shoot through states, is supported by a help element, whose quality relies on upon the shoot through obligation proportion for a given adjustment record. The diode D1 is killed because of the converse predisposition voltage [10].

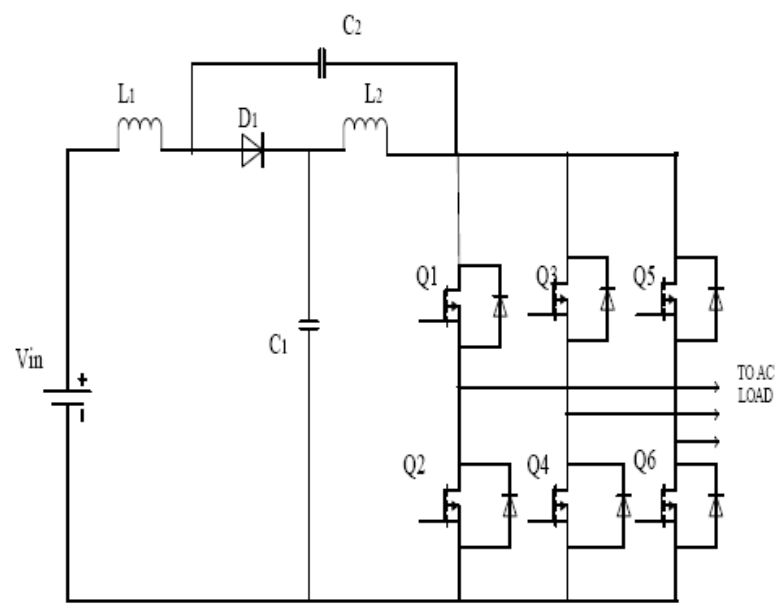

Fig. 1: Quasi Z source inverter

\section{c) QZSI-Battery using SPWM}

Fig 2 shows only one of the energy put away QZSI topologies, we interface the battery in parallel to the capacitor $\mathrm{C} 1$ [11].They have regular focuses: 1) There are three power sources/shoppers, i.e., PV boards, battery, and the matrix/burden, and 2) the length of controlling two power streams, the third one consequently coordinates the power contrast, as indicated by the power equation

$$
P \text { in }-P \text { out }+P B=0
$$

Where Pin, Pout, and PB are the PV board control, the outcome power of the inverter, and the battery power, individually [12]. The power Pin is constantly positive on the grounds that the PV board is single directional power supply; PB is sure when the battery conveys energy and negative while retaining energy, and Pout is certain when the inverter infuses energy to the grid [13]. Table I shows the system parameters for proposed simulation framework.

Table 1: System parameters

\begin{tabular}{|c|c|c|}
\hline S. No. & Parameter & Parametric values \\
\hline 1 & Input AC voltage & $150 \mathrm{v}$ \\
\hline 2 & Z network components & \\
& $\mathrm{C}_{1}=\mathrm{C}_{2}$ & $100 \mu \mathrm{F}$ \\
& $\mathrm{L}_{1}=\mathrm{L}_{2}$ & $2 \mathrm{mH}$ \\
\hline 3 & Output filter components & \\
& $\mathrm{L}$ & $1 \mathrm{mH}$ \\
& $\mathrm{C}$ & $10 \mu \mathrm{F}$ \\
\hline
\end{tabular}

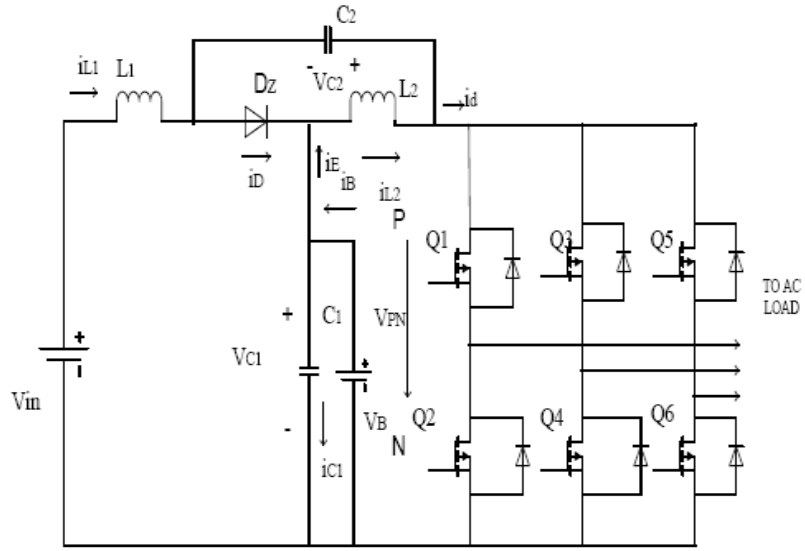

Figure 2: New energy-stored QZSI for PV power generation 


\section{International Journal of Science and Research (IJSR) \\ ISSN (Online): 2319-7064}

Index Copernicus Value (2013): 6.14 | Impact Factor (2015): 6.391

d) Sinusoidal pulse width modulation

The voltage source inverter that utilization PWM switching systems have a DC information voltage $(\mathrm{VDC}=\mathrm{VS})$ that is normally consistent in greatness. The inverter occupation is to take this DC include and to give AC outcome, where the extent and recurrence can be controlled. There are a few systems of Pulse Width Modulation (PWM) [14]. The productivity parameters of an inverter, for example, switching misfortunes and consonant diminishment are primarily relied on upon the balance techniques used to control the inverter.

\section{Results}

Results of our proposed technology will be like following below figures:

Run the Matlab platform and initialize the project.

Fig. 3 presents an overall proposed architecture of SVPWM control of quasi Z-square inverter.

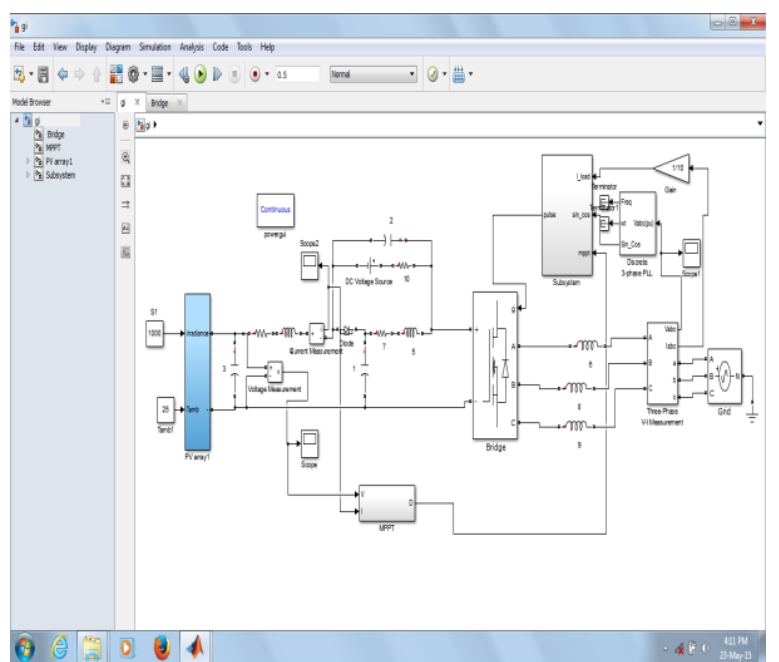

Figure 3: Overall schematic diagram of SVPWM Control of quasi Z-source inverter with battery for grid connected PV System

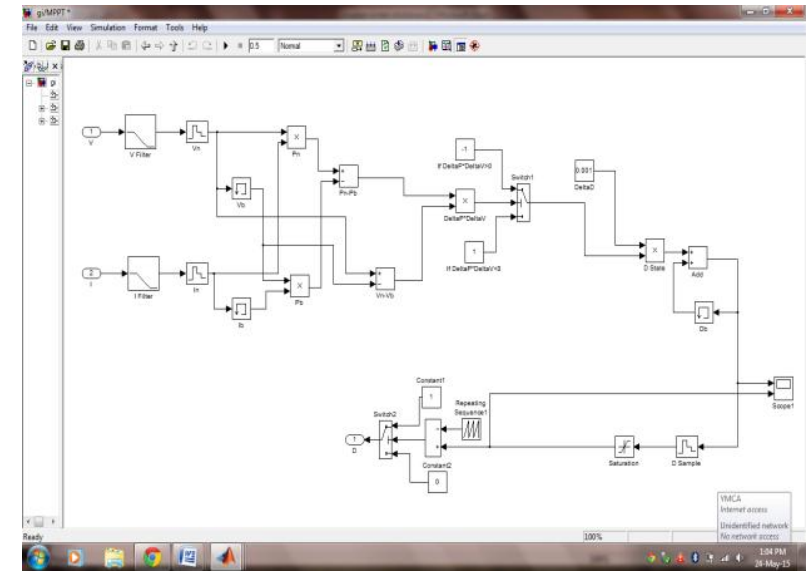

Figure 4: Architecture of MPPT (Maximum Power Point Tracking) Algorithm

The fig. 4 presents the Architecture of MPPT (Maximum Power Point Tracking) Algorithm.

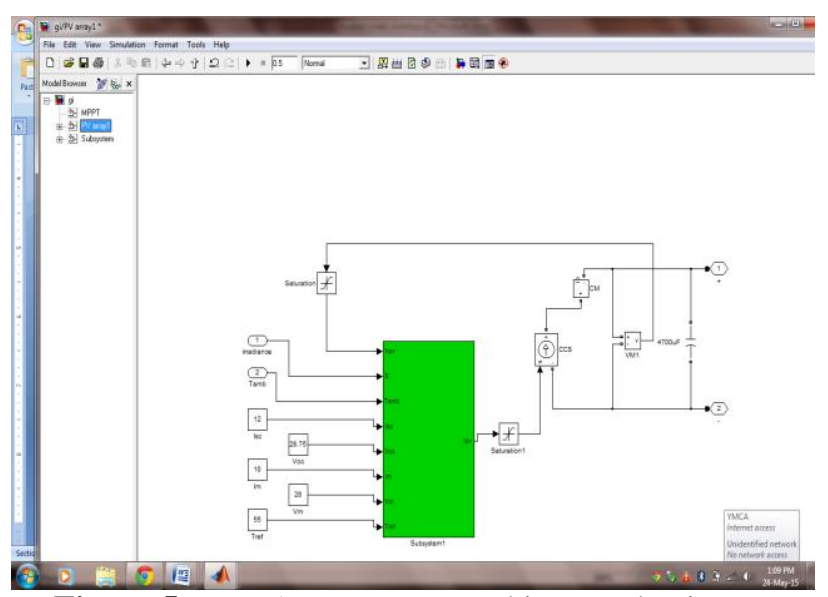

Figure 5: PV -Array system architecture having a no of subsystems embedded and joint together to form a grid pattern

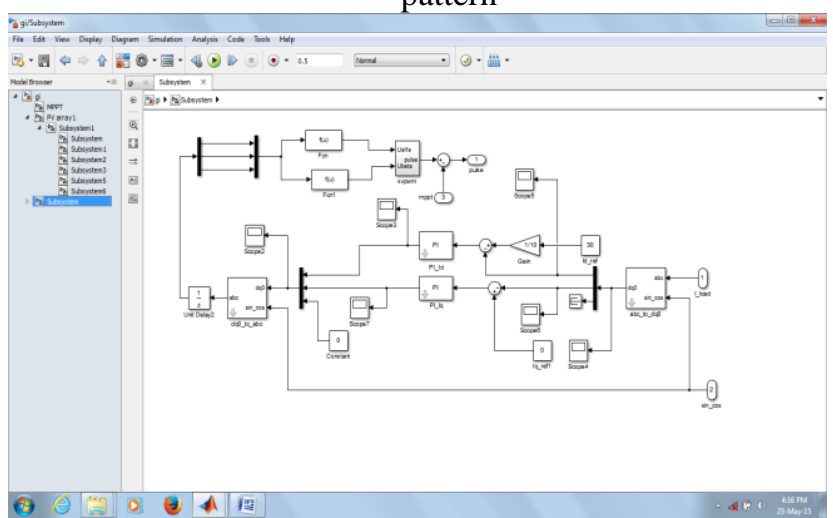

Figure 6: Internal Diagram of the Subsystem Block of the main Architecture

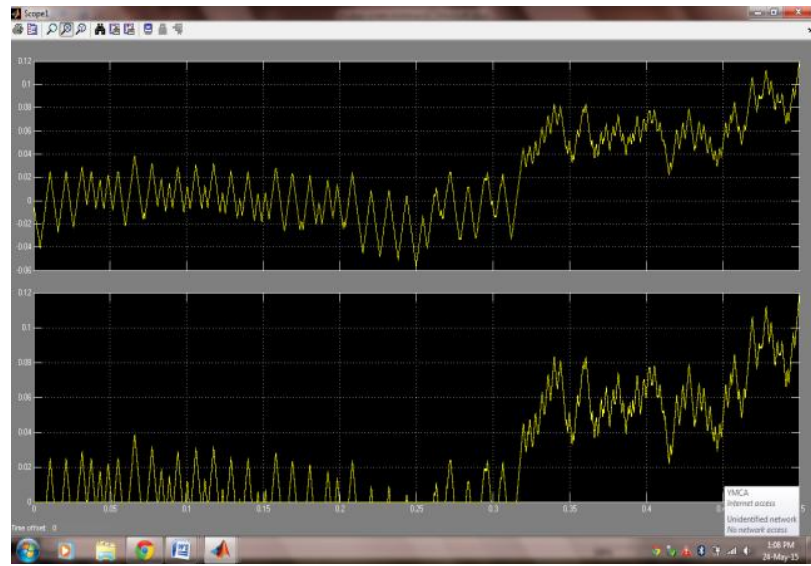

Figure 7: Output waveforms of MPPT as irradiation and temperature 


\section{International Journal of Science and Research (IJSR) \\ ISSN (Online): 2319-7064}

Index Copernicus Value (2013): 6.14 | Impact Factor (2015): 6.391

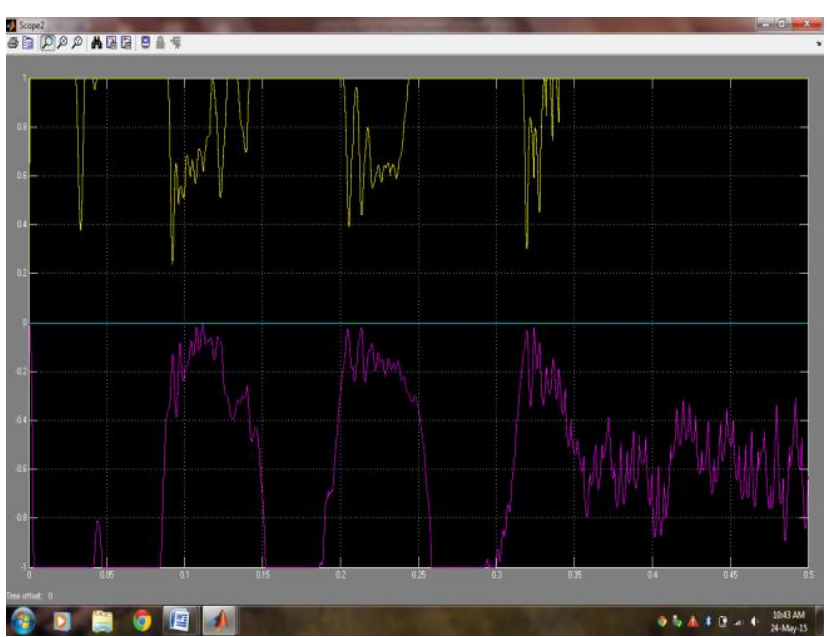

Figure 8: Scope 2 output of subsystem block

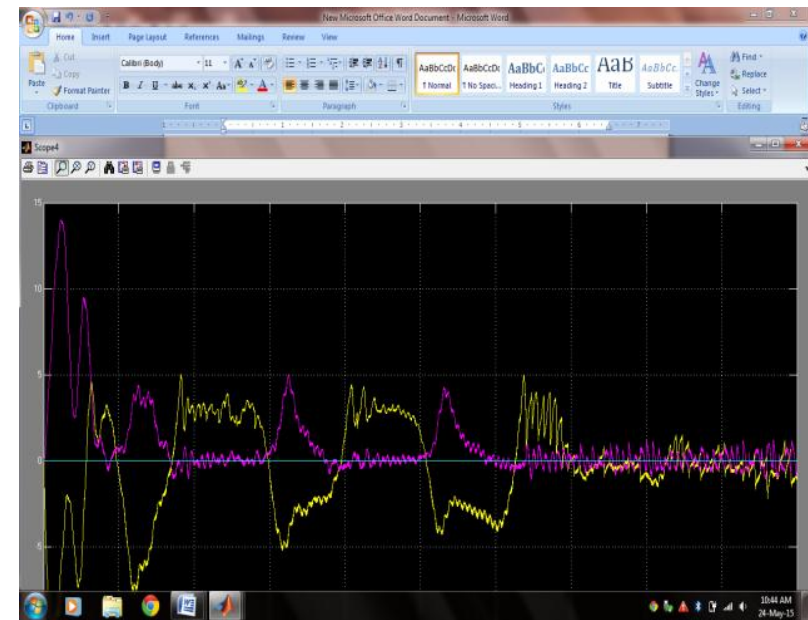

Figure 9: Output at scope 4 of subsystem block

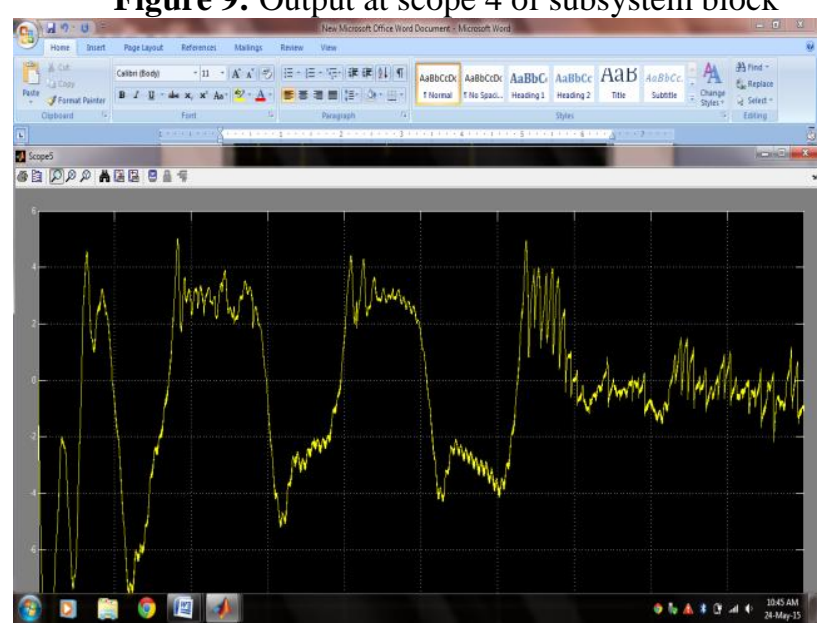

Figure 10: Output at scope 5 of subsystem block
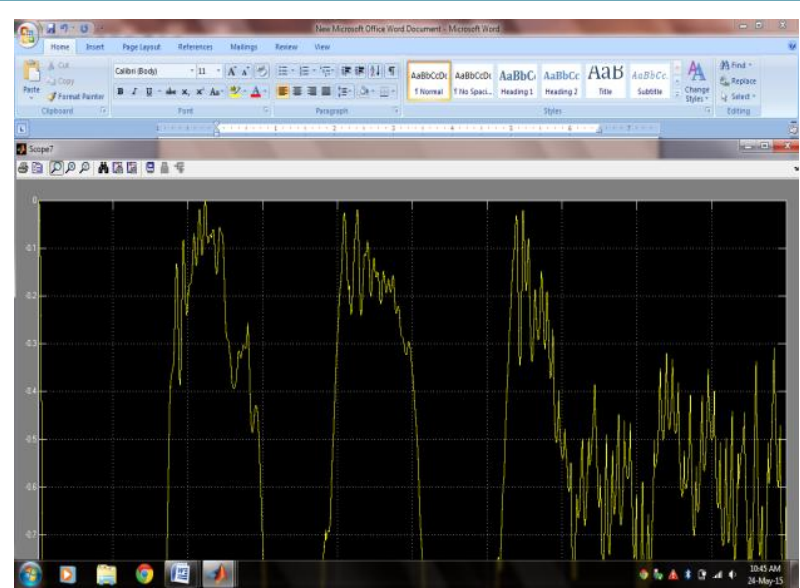

Figure 11: Output at scope 7 of subsystem block

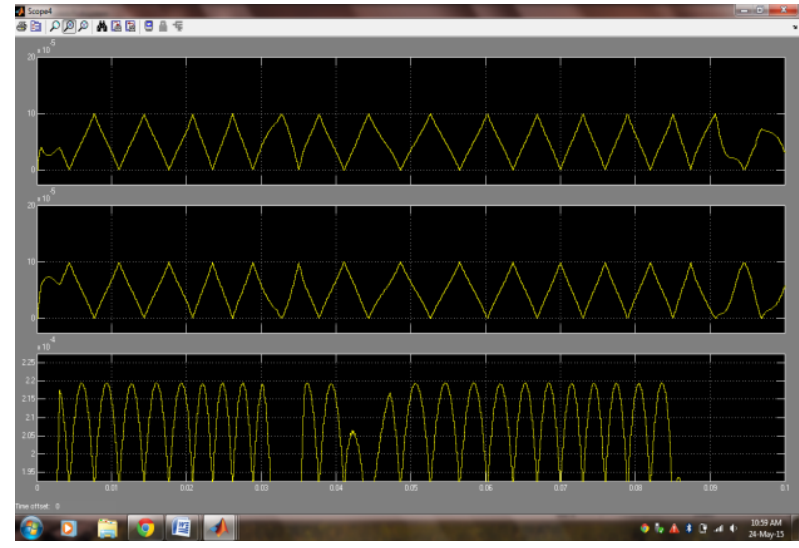

Figure 12: Output at scope 4 of SVPM block

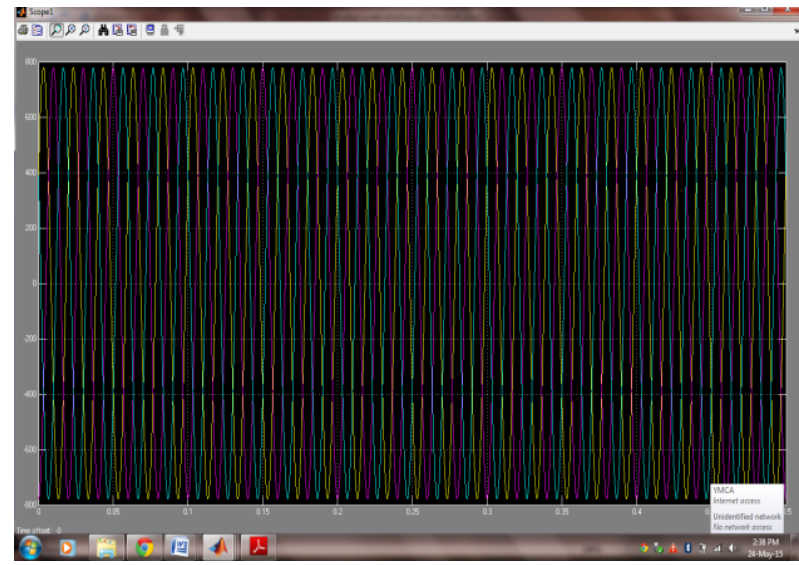

Figure 13: Output frequency which is $50 \mathrm{~Hz}$ as desired

\section{Conclusions}

In this paper, a novel topology for energy put away QZSI has been proposed to beat the weakness of the current design in PV power framework. The experimental research, simulation results exhibited in this work show the proposed energy put away QZSI with SVPWM procedure. QZSI utilized for solar oriented power applications, where both improving and fluctuating should be possible in a single stage. The battery operation can adjust the variances from PV board and supply the constant energy to the lattice/load. The proposed energy put away QZSI have some new points of interest more appropriate for application in PV frameworks. This will make the PV framework less difficult and lower cost.

\section{Volume 5 Issue 6, June 2016} www.ijsr.net 


\section{International Journal of Science and Research (IJSR) \\ ISSN (Online): 2319-7064}

Index Copernicus Value (2013): 6.14 | Impact Factor (2015): 6.391

\section{Acknowledgment}

The authors convey their heartfelt thanks to NAVNIDHI SHARMA, (HEAD OF DEPARTMENT ELECTRICAL ENGINEERING) EMAX GROUP OF COLLEGES and Dr. KAMAL KUMAR SHARMA, (DIRECTOR) EMAX GROUP OF COLLEGES, for providing them the required facilities to complete the project successfully. This paper is used to carry out research work about to optimize power output from panel depends upon both irradiance and temperature.

\section{References}

[1] F. Bradaschia, M. C. Cavalcanti, P. E. P. Ferraz, F. A. S. Neves, E. C. dos Santos, and J. H. G. M. da Silva, "Modulation for three-phase transformer less Z-source inverter to reduce leakage currents in photovoltaic systems," IEEE Trans. Ind. Electron., vol. 58, no. 12, pp. 5385-5395, Dec. 2011.

[2] W. Li and X. He, "Review of nonisolated high-step-up DC/DC converters in photovoltaic grid- connected applications," IEEE Trans. Ind. Electron., vol. 58, no. 4, pp. 1239-1250, Apr. 2011.

[3] Q.Tran, T.Chun, J. Ahn, and H.-H. Lee, "Algorithms for controlling both the DC boost and AC output voltage of Zsource invert-er," IEEE Trans.Ind. Electron., vol. 54, no. 5, pp. 2745-2750, Oct. 2007.

[4] C. J. Gajanayake, D. M. Vilathgamuwa, and C. L. Poh, "Development of a comprehensive model and a multi loop controller for Z-source inverter DG systems," IEEE Trans. Ind. Electron., vol. 54, no. 4, pp. 23522359, Aug. 2007.

[5] M. Shen, J. Wang, A. Joseph, F. Z. Peng, L. M. Tolbert, and D. J. Adams, "Constant boost control of the $\mathrm{Z}$ source inverter to mini-mize current ripple and voltage stress,'IEEETrans.Ind.Appl.,vol. 42,no.3,pp.770-778,May/Jun. 2006.

[6] Baoming Ge, Haitham Abu-Rub, Fang Zheng Peng, Qin Lei, Aníbal T. de Almeida, Fernando J. T. E. Ferreira, Dongsen Solar, and Yushan Liu, "An EnergyStored Quasi-Z-Source Inverter for Application to Photovoltaic Power System," IEEE Trans. Ind. Electron., vol. 60, no. 10, pp. 4468-4481, Oct. 2013

[7] Huang Y, Shen MS, Peng FZ, Wang J. Z-source inverter for residential photovoltaic systems. IEEE Trans Power Electron 2006; 21(6):1776-82.

[8] C. J. Gajanayake, D. M. Vilathgamuwa, and C. L. Poh, "Development of a comprehensive model and a multi loop controller for Z-source inverter DG systems," IEEE Trans. Ind. Electron., vol. 54, no. 4, pp. 23522359, Aug. 2007.

[9] Bradaschia F, Cavalcanti MC, Ferraz PEP, Neves FAS, dos Santos EC, da Silva JHGM. Modulation for threephase transformerless Z-source inverter to reduce leakage currents in photovoltaic systems. IEEE Trans Indust Electron 2011;58(12):5385-95.

[10] Vinnikov D, Roasto I. Quasi-Z-source-based isolated DC/DC converters for distributed power generation. IEEE Trans Indust Electron 2011;58(1):192-201.

[11] Anderson J, Peng FZ. Four quasi-Z-source inverters. In: Proceedings of IEEE power electronics specialists conference, Rhodes, Greece; 2008. p. 2743-9.
[12] Park JH, Kim HG, Nho EC, Chun TW, Choi J. Gridconnected PV system using a quasi-Z-source Inverter. In: Proceedings of the twenty-fourth annual IEEE applied power electronics conference and exposition, Washington (DC, USA); 2009. p. 925-9.

[13] Peng FZ, Shen MS, Holland K. Application of Zsource Inverter for traction drive of fuel cell - battery hybrid electric vehicles. IEEE Trans Power Electron 2007; 22(3):1054-61.

[14] Peng FZ. Z-source inverter. IEEE Trans Indust Appl 2003;39(2):504-10.

Volume 5 Issue 6, June 2016 www.ijsr.net

Licensed Under Creative Commons Attribution CC BY 